\title{
Antioxidant activities and anti-inflammatory effects of fresh and air-dried Abeliophyllum distichum Nakai leaves
}

\author{
Seong Jun Chang ${ }^{1}$, Nam Bae Jeon ${ }^{1}$, Joo Won Park ${ }^{1}$, Tae Won Jang ${ }^{2}$, \\ Jin Boo Jeong ${ }^{2}$, Jae Ho Park ${ }^{3 *}$ \\ ${ }^{1}$ Teakyung food and processing R\&D center, Seoul 07057, Korea \\ ${ }^{2}$ Department of Medicinal Plant Resources, Andong National University, Andong 36729, Korea \\ ${ }^{3}$ Department of Medicinal Plant Science, Jungwon University, Goesan 28024, Korea
}

\section{건조방법에 따른 미선나무 잎의 항산화 및 항염증 효과}

\author{
장성준 ${ }^{1} \cdot$ 전남배 $^{1} \cdot$ 박주원 $^{1} \cdot$ 장태 원 ${ }^{2} \cdot$ 정진부 ${ }^{2} \cdot$ 박재호 $^{3 *}$ \\ ${ }^{1}$ 태경농산( 주) 연구소, ${ }^{2}$ 안동대학교 생약자원학과, ${ }^{3}$ 중원대학교 생약자원개발학과
}

\begin{abstract}
In this study, we evaluated the antioxidant activity and anti-inflammatory effects of Abeliophyllum distichum (A. distichum) leaves that were prepared via air-drying. Fresh and air-dried $A$. distichum leaves were examined via 1,1-diphenyl-2-picryl hydrazyl (DPPH) radical, and 2,2'-azino-bis(3-ethylbenzothiazoline-6-sulfonic acid) diammonium salt (ABTS) radical scavenging assay and measurements of the reducing power. The suppression effects on inflammation of the leaves were analyzed by a western blot and RT-PCR on LPS-induced RAW 264.7 cells. As a result, the antioxidant activity of the fresh leaves was found to be more effective than that of the air-dried leaves. Also, the fresh leaves were more effective in suppressing the protein and mRNA levels of iNOS and COX-2 than the air-dried leaves, thereby indicating the better anti-inflammatory effects. In addition, the contents of phenolic compounds and acteoside were analyzed by high-performance liquid chromatography (HPLC). The results showed that the acteoside content decreased with the use of the air-drying method, while there was no change in the content of phenolic compounds. Therefore, this study indicated that fresh $A$. distichum leaves potential antioxidant and suppression activities of various factors that are involved in the production of NO, which were found to be better than those of air-dried $A$. distichum leaves. These biological activities were also found to be independent of the content of phonolic compounds and were assumed to be directly or indirectly related to the content of acteoside.
\end{abstract}

Key words : Abeliophyllum distichum, anti-inflammatory, drying methods, iNOS

\section{서 론}

체내에서 생성되는 다양한 활성산소종(ROS, reactive oxygen species)은 정상적인 경우에는 체내에 존재하는 항 산화 시스템에 의해 활성 산소종이 제거되지만, 대부분의

\footnotetext{
*Corresponding author. E-mail : parkjh@jwu.ac.kr

Phone : 82-43-830-8614, Fax : 82-43-830-8679

Received 6 December 2017; Revised 25 January 2018; Accepted 26 January 2018.

Copyright (c) The Korean Society of Food Preservation. All rights reserved.
}

전자 운반 과정 중 불완전하게 환원되거나 cytokine 등 다양 한 작용의 자극에 의해 과다하게 발생된 활성산소종은 세포 에 산화적 손상을 주게 된다(1). 따라서 이러한 활성 산소종 에 의한 산화작용으로부터 생체를 보호할 수 있는 항산화제 에 대한 연구들이 활발히 진행되고 있다. 특히 천연물에서 기인하는 천연 항산화제에 대한 연구가 주목받고 있다. 그 중에서, 페놀류 화합물 및 다양한 식물에서 유래된 물질인 식물화학물질(Phytochemicals)은 식물의 2차 대사산물에 의해 생성되며, 이러한 식물화학물질은 항산화, 항암효과 를 포함한 다양한 약리작용을 통해 체내 활성산소 제어에 도움을 준다(2). 또한 활성산소종은 다양한 병리적 증상에 
영향을 미치며 염증 반응과도 관련이 깊다(3). 염증 반응은 미생물 감염, 내독소, 조직 손상 등에 대한 체내 방어기작으 로, 조직의 구조와 기능을 정상적으로 회복하기 위해 일어 나는 필수적인 반응이다. 정상적인 염증반응은 시간이 지 남에 따라 염증촉진성 매개체(pro-inflammatory mediators) 의 생성은 감소되고, 항염증성 매개체(anti-inflammatory mediators)는 증가됨으로써 염증반응이 스스로 제한되는 조절과정을 가지고 있다(4). 체내의 대식세포(macrophages) 는 이러한 염증 반응에 중요한 역할을 하고 있다. Lipopolysaccharid(LPS)에 의하여 유발된 inducible nitric oxide synthase(iNOS)는 칼슘 비의존성 경로를 통해 발현되 며, cyclooxygenase-2(COX-2)는 염증 부위에서 염증성 자 극에 의하여 다량 유도되어 발현된다. iNOS와 COX-2는 정상 상태에서는 발현되지 않으나 LPS 등에 의해서 발현이 유도되면 다량의 $\mathrm{NO}$ 를 생성하거나 prostaglandin E2(PGE2), tumor necrosis factor- $a(\mathrm{TNF}-a)$ 등과 같은 염증발현 중개 물질이 발생 된다(5-7). 염증반응은 인체의 생체조직을 방 어하기 위한 기전이지만 이러한 물질들의 과도한 생성을 통한 염증반응은 점막손상을 유발하고 심각할 경우 암을 비롯한 다양한 질병의 원인이 되기도 한다(8). 따라서 염증 성 매개체들의 생성을 억제하거나 염증발현 중개 물질등을 억제하는 천연 유래 화합물의 탐색은 부작용이 적은 항염증 치료제 개발을 위한 방편으로 주목 받고 있다.

미선나무(Abeliophyllum distichum)는 물푸레나무과의 식 물로, 종자의 형태가 부채를 닮아 미선(尾扇)나무로 불리는 관목이며 우리나라에서 자생하는 한국 특산식물이다. 또한 세계적으로 1 속 1 종의 희귀식물이며, 현재 환경부는 미선 나무를 보호 야생 식물로 지정하고 있다(9). 미선나무 잎에 대한 연구로는 미선나무 잎이 포함하고 있는 glycoside에 대한 연구(10), 미선나무 잎의 에틸아세테이트 분획물의 항염증 활성(11), 항산화 활성 및 산화적 DNA 손상억제 활성(9) 등이 연구되어 있으며, 미선나무가 포함하고 있는 acteoside는 간 보호 효과(12), 항염증(13), 항산화 효과 (14-16) 등 다양한 생리활성을 나타낸다고 알려져 있다. 하 지만 건조방식에 따른 미선나무 잎 물 추출물의 항산화 및 항염증 활성 및 acteoside의 함량에 대한 연구는 미흡하 다. 식품이나 화장품 원료로 사용함에 있어 효과적인 물 추출물의 건조방식에 따른 항산화, 항염증 효과 및 acteoside의 함량을 비교하였다.

\section{재료 및 방법}

\section{실험재료}

본 연구에 사용된 미선나무 잎은 충북 괴산군 괴산읍 충민로기곡길 78 성불산자연휴양림 미선향 테마파크에서 인공증식 재배지로부터 채취 및 건조하였으며, 중원대학교
생약자원개발학과에서 동정된 시료를 사용하였다(voucher number: JWU-031). 본 실험에 사용된 Dulbecco's modified Eagle's medium(DMEM), 10\%(v/v) fetal bovine serum, penicillin/streptomycin, trypsin은 Hyclone(Laboratories Inc., Logan, UT, USA) 제품을 사용하였다. HPLC grade의 methanol, petroleum ether, ethyl acetate, chloroform, acetonitrile 및 dimethyl sulfoxide는 Merck(HPLC grade, Frankfurter, Darmstadt, Germany)사의 제품을 사용하였다. 나머지 시약 은 Sigma-Aldrich(St. Louis, MO, USA)사의 제품을 사용하 였다. 기타 시약 및 기기는 별도 표기하였다. 모든 항체는 abcam(Cambrige, MA, USA)의 제품을 사용하였다.

\section{가공 및 저장 조건}

미선나무 잎은 생체 및 건조 시료로 구분하였다. 생체 미선나무 잎(생잎)은 채취 즉시 사용하였으며, 건조시료(건 조잎)는 7일간 음건하여 시료로 사용하였다. 각 시료 100 $\mathrm{g}$ 에 증류수 $1 \mathrm{~L}$ 로 침지하여 autoclave에서 $121^{\circ} \mathrm{C}, 1.2 \mathrm{~atm}$ 조건으로 15 분 간 추출하였으며, 이 추출물을 동결건조하 여 시료로 사용하였다.

\section{$\mathrm{DPPH}$ 라디칼 소거활성}

$\mathrm{DPPH}$ 를 이용한 전자 공여능은 Bondet 방법(17)을 참고 하여 측정하였다. DPPH solution은 $300 \mu \mathrm{M}$ 1,1-diphenyl2-picryl hydrazyl(DPPH)를 $515 \mathrm{~nm}$ 에서 흡광도 값이 1.00 이 되도록 ethanol을 이용하여 희석 준비하였다. 각 농도별 추 출물 $(0.32,1.6,8,40,200 \mu \mathrm{g} / \mathrm{mL}) 40 \mu \mathrm{L}$ 에 DPPH solution $760 \mu \mathrm{L}$ 를 첨가한 후 $37^{\circ} \mathrm{C}$ 에서 20 분 반응시켜 $\mathrm{UV} /$ Visible spectrophotometer(Xma-3000PC, Human Co., Seoul, Korea) 를 이용하여 $515 \mathrm{~nm}$ 에서 흡광도를 측정하였다.

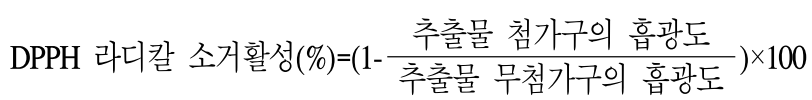

\section{ABTS 라디칼 소거활성}

$\mathrm{ABTS}$ 라디칼 소거 활성 능력은 Van den Berg 등의 방법 (18)을 참고하여 측정하였다. ABTS solution은 $7.4 \mathrm{mM}$ 2,2'-azino-bis(3-ethylbenzothiazoline-6-sulfonic acid) diammonium salt와 $2.6 \mathrm{mM}$ potassium persulfate를 혼합하여 24시간 ABTS radical을 형성시킨 후 증류수를 이용하여 $734 \mathrm{~nm}$ 에서 흡광도 값이 0.70 이 되도록 희석하였다. 각 농도별 추출물 $40 \mu \mathrm{L}$ 에 $\mathrm{ABTS}$ solution $760 \mu \mathrm{L}$ 를 첨가한 후 $37^{\circ} \mathrm{C}$ 에서 20 분 반응시켜 UV/Visible spectrophotometer (Xma-3000PC, Human Co.)를 이용하여 $734 \mathrm{~nm}$ 에서 흡광도 를 측정하였다.

$\mathrm{ABTS}$ 라디칼 소거활성 $(\%)=\left(1-\frac{\text { 추출물 첨가구의 흡광도 }}{\text { 추출물 무첨가구의 흡광도 }}\right) \times 100$ 


\section{환원력}

환원력은 Oyaizu의 방법(19)을 참고하여 측정하였다. 각 농도별 추출물 $100 \mu \mathrm{L}$ 에 $0.2 \mathrm{M}$ potassium phosphate buffer(pH 6.6) $250 \mu \mathrm{L}$ 과 $1 \%$ potassium hexacyanoferrate(III) $250 \mu \mathrm{L}$ 을 혼합한 후, $50^{\circ} \mathrm{C}$ 에서 20 분 반응시킨 후 찬물로 냉각하여, trichloroacetic acid(TCA) $250 \mu \mathrm{L}$ 를 첨가하였다. 위 반응액을 $2,000 \times g$ 에서 5 분간 원심 분리하여 상등액 $400 \mu \mathrm{L}$ 에 증류수 $400 \mu \mathrm{L}$ 와 $0.10 \%$ ferric chloride $16 \mu \mathrm{L}$ 를 첨가하여 혼합한 후, UV/Visible spectrophotometer(Xma$3000 \mathrm{PC}, \mathrm{Human} \mathrm{Co}$.)를 이용하여 $700 \mathrm{~nm}$ 에서 흡광도를 측 정하였다.

\section{총 페놀 함량 분석}

총 페놀 함량은 Folin-Denis 방법(20)을 참고하여 측정하 였다. 추출물 $50 \mu \mathrm{L}$ 와 증류수 $950 \mu \mathrm{L}$, Folin $500 \mu \mathrm{L}$ 를 혼합한 후, $20 \%$ sodium carbonate $2.5 \mathrm{~mL}$ 를 넣어 40 분간 실온에서 반응시켰다. 반응물을 흔들지 않고 맑은 액체를 UV/Visible spectrophotometer를 이용하여 $725 \mathrm{~nm}$ 에서 흡광도를 측정 하였다. Standard는 tannic acid를 사용하였고, 정량 직선방 정식을 사용하였다.

\section{Acteoside 함량 분석}

Acteoside의 High performance liquid chromatography (HPLC) 분석은 Waters 2695 system(Waters, Milford, MA, USA)과 Waters 2487 Dual $\lambda$ absorbance detector(Waters)를 통해 분석하였다. 실험에 사용된 시료 및 표준품은 $1 \mathrm{mg}$ 을 취하여 $1 \mathrm{~mL}$ 의 메탄올에 용해하여 $0.45 \mu \mathrm{m}$ membrane filter(Waters)를 이용해 여과하였고, 시료 $10 \mu \mathrm{L}$ 를 acetonitrile 및 $1 \%$ acetic acid/ $\mathrm{H}_{2} \mathrm{O}$ 를 $1 \mathrm{~mL} / \mathrm{min}$ 로 0-20분까지 10:90에서 50:50로 변화하는 용매 비율로 분석하였다. Waters XBridge ${ }^{\mathrm{TM}}$ $\mathrm{C}_{18}$ column $(4.6 \mathrm{~mm} \times 250 \mathrm{~mm})$ packed with $5.0 \mu \mathrm{m}$ diameter particles(Waters)를 이용하여 흡광도 $335 \mathrm{~nm}$ 에서 분석하였 으며, 시료의 acteoside 함량은 표준품과 비교하여 동정 및 정량하였다. 표준품은 Sigma-aldrich사의 제품을 이용하였 으며, 표준품의 정량 직선방정식을 사용하여 정량하였다.

\section{세포 배양}

본 연구에 사용된 Raw 264.7 세포는 American Type Culture Collection(ATCC, Manassas, VA, USA)에서 분양받 아 실험하였다. 세포는 $1 \%$ penicillin/streptomycin 및 $10 \%$ fetal bovine serum이 포함된 $\mathrm{DMEM}$ 에서 $37^{\circ} \mathrm{C}, 5 \% \mathrm{CO}_{2}$ 조건 하에 배양하였다.

\section{세포 생존율}

Raw 264.7 세포를 96-well plate에 $1.0 \times 10^{4}$ cells/well의 밀도로 분주하여, 24 시간 배양한 후 농도 별로 시료를 처리 하였다. 시료 처리 24시간 후 alamarBlue® Cell Viability
Reagent(Thermo Fisher Scientific, Waltham, MA, USA)을 배지의 총량의 $20 \%$ 씩 처리하여 2 시간 배양하였다. 반응 후 UV/Visible spectrophotometer(Xma-3000PC, Human Co.) 을 이용하여 $570 \mathrm{~nm}$ 에서 흡광도를 측정하여 세포생존율을 확인하였다.

\section{$\mathrm{NO}$ 생성량 측정}

Raw 264.7 세포를 96-well plate에 $1.0 \times 10^{4}$ cells/well의 밀도로 분주하여, 24시간 배양한 후 농도 별로 시료를 처리 하였다. 시료 처리 1시간 후 LPS를 처리하여 24시간 배양한 상등액을 NO 생성량 측정에 사용하였다. 세포 상등액에 Griess reagent(1\% sulfanilamide, $0.1 \% \mathrm{~N}-1$-naphthylenediamine dihydrochloride, and $2.5 \%$ phosphoric acid)를 처리하여 540 $\mathrm{nm}$ 에서 흡광도를 측정하였다.

\section{Western blot}

Raw 264.7 세포를 6-well plate에 $1.0 \times 10^{5}$ cells/well의 밀 도로 분주하여, 24시간 배양한 후 농도 별로 시료 및 LPS를 처리하였다. 시료 처리 24시간 후 PBS로 두 번 세척한 후, protease inhibitor cocktail을 포함한 Radio Immuno Precipitation Assay(RIPA) buffer로 용해한 후 얼음에서 30 분간 정치시켰다. 세포 용해액을 $4{ }^{\circ} \mathrm{C}, 12,000 \mathrm{rpm}$ 에서 20 분 간 원심분리하고, 상층액은 Bradford 시약(Bio-rad, Hercules, CA, USA)을 이용하여 단백질 정량을 실시하였 다. 세포 용해액은 $2 \times$ Lamilae buffer와 혼합하여 $95^{\circ} \mathrm{C}$ 에서 5 분 간 가열 후 각 $20 \mu \mathrm{g}$ 단백질량에 해당하는 시료를 $10 \%$ SDS-PAGE에서 전기 영동하여 분리하였다. 전기 영동된 단백질은 polyvinylidene difluoride membrane(PVDF) 막에 옮겨 상온에서 1시간 동안 blocking(5\% skim milk in TBST) 하였다. 1 차 항체를 $1: 2,000$ 으로 희석하여 $4^{\circ} \mathrm{C}$ 에서 overnight 처리하였다. 이후 10 분 간격으로 TBST로 3 회 세 척하고, 2 차 항체 $1: 5,000$ 으로 희석하여 1 시간 동안 반응시 켰다. 이후 10 분 간격으로 TBST로 3 회 세척하고 enhanced chemiluminescence(ECL) western blotting detection kit(Bio$\mathrm{rad}$ 로 반응하였다. 단백질 밴드는 FluorChem $\mathrm{E}(\mathrm{Cell}$ biosciences, Santa Clara, CA, USA)로 촬영하여 확인하였다.

\section{Total RNA 추출 및 $\mathrm{cDNA}$ 합성}

Raw 264.7 세포를 6-well plate에 $1.0 \times 10^{5}$ cells/well로 분 주하여, 24시간 배양한 후 농도 별로 시료를 처리했다. 시료 처리 48시간 후 PBS로 두 번 세척한 후, Nucleo $\mathrm{Spin}^{\circledR} \mathrm{RNA}$ Plus(Macherey-Nagel, Duren, Germany)를 이용하여 total $\mathrm{RNA}$ 를 얻었다. 모든 과정은 $4^{\circ} \mathrm{C}$ 에서 진행되었으며, Quantus fluorometer RNA system(Promega, Madison, WI, USA)를 사용하여 정량하였으며, $\mathrm{cDNA}$ 합성을 위해 $1 \mathrm{\mu g}$ 의 total RNA를 사용하여 ReverTra Ace -a- ${ }^{\circledR}$ (Toyobo, Osaka, Japan) 를 이용하여 $\mathrm{cDNA}$ 를 합성하였다. 


\section{RT-PCR}

cDNA상의 타겟 유전자를 증폭시키기 위하여 Quick $\mathrm{Taq}^{\circledR}$ HS Dye Mix(Toyobo, Osaka, Japan)와 합성한 cDNA, forward primer와 reverse primer로 PCR을 수행하였다. PCR 의 조건은 다음과 같다. $94^{\circ} \mathrm{C}$ 로 2 분 간 denaturation을 시킨 후, $94^{\circ} \mathrm{C}$ 에서 30 초 간 denaturation 후 $55^{\circ} \mathrm{C}$ 에서 30 초 간 annealing, $68^{\circ} \mathrm{C}$ 에서 1 분 간 extension을 25 cycle 반복하였고 마지막 단계로 $72^{\circ} \mathrm{C}$ 에서 10 분 간 extension하였다. House keeping gene으로 $\beta$-actin을 사용하였고 $2 \%$ agarose gel(Affymetrix, Cleveland, OH, USA)로 UV 상에서 band를 확인하였다. 각 primer의 서열은 다음과 같다.

iNOS forward 5'-AAT GGC AAC ATC AGG TCG GCC ATC ACT-3', reverse 5'-GCT GTG TGT CAC AGA AGT CTC GAA CTC-3'

COX-2 forward 5'-GGA GAG ACT ATC AAG ATA GT-3', reverse 5'-ATG GTC AGT AGA CTT TTA CA-3'.

GADPH forward 5'-AAC TTT GGC ATT GTG GAA GG-3', Reverse 5'-ATG CAG GGA TGA TGT TCT GG-3'

\section{통계학적 분석}

모든 실험 결과는 3 번 이상 수행하였으며, 통계분석은 SPSS 18.0(Statistical Package for the Social Sciences)을 이용 하여 각 실험의 평균과 표준편차를 계산하였고, ANOVA를 통한 $\mathrm{p}<0.05$ 수준에서 Duncan 다중검정법(Duncan's multiple range test)으로 사후 검정하여 각 실험의 유의성을 검증하였다.

\section{결과 및 고찰}

\section{항산화 활성}

본 연구는 건조 방식에 따른 미선나무 잎 물 추출물의 항산화 및 항염증 활성에 대한 비교 분석을 위해 실행되었 다. 항산화 활성의 기작은 유리기와 반응하는 것으로, 유리 기 소거작용은 활성라디칼(free radical)에 전자를 공여하여 식물 중의 항산화 효과나 인체에서 노화를 억제하는 척도로 사용된다. DPPH와 $\mathrm{ABTS}$ 는 비교적 안정한 라디칼을 갖는 물질로 DPPH 라디칼 소거 활성은 수소 공여체의 활성을 측정하는 방법으로 페놀성 화합물, 방향족 아민류 및 아스 코르빈산 등에 의해 수소나 전자를 받아 환원되어 보라색이 탈색 되는 원리를 이용한 방법이며, 항산화 물질을 탐색하 기 위해 많이 이용되고 있다(21).

건조 방식에 따른 미선나무 잎의 항산화 활성을 평가하 기 위해 DPPH 라디칼 소거활성, ABTS 라디칼 소거활성 및 환원력으로 평가하였다. DPPH 라디칼 소거활성에서 (Fig. 1), 추출물의 농도가 증가함에 따라 DPPH 라디칼 소거 활성이 증가하였으며 건조잎 추출물 농도 $200 \mu \mathrm{g} / \mathrm{mL}$ 에서
$82.7 \pm 1.3 \%, 40 \mu \mathrm{g} / \mathrm{mL}$ 에서 $68.0 \pm 1.1 \%$ 로 생잎 추출물 $90.1 \pm 0.9 \%, 70.7 \pm 0.7 \%$ 과 비교하여 생잎 추출물이 높은 활 성을 나타냈다. 또한 $\mathrm{IC}_{50}$ (inhibitory concentration) 값은 건 조잎 $22.7 \mu \mathrm{g} / \mathrm{mL}$, 생잎 $18.0 \mu \mathrm{g} / \mathrm{mL}$ 으로 나타났다.

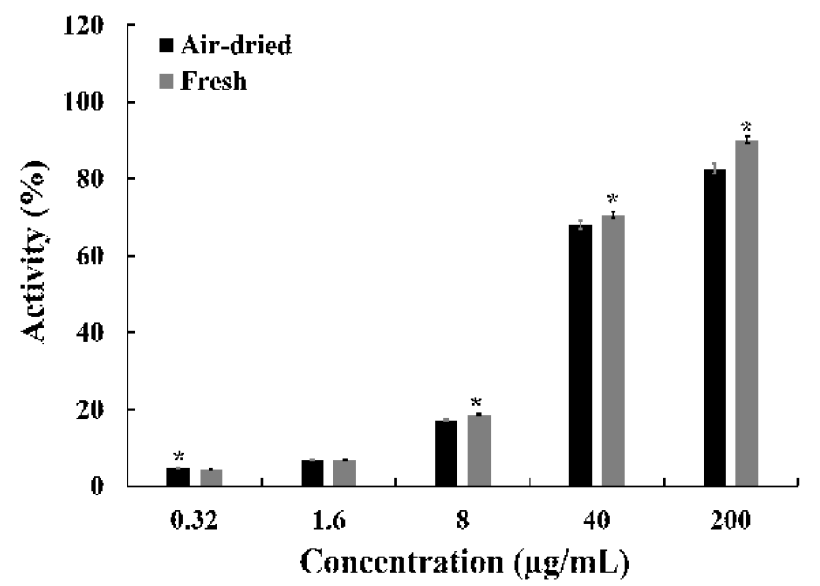

Fig. 1. DPPH radical scavenging activity of fresh and air-dried Abeliophyllum distichum Nakai leaves.

All data are from one experiment, representing three independent experiments $(\mathrm{p}<0.05$, air-dried-treated group vs fresh-treated group).

$\mathrm{ABTS}$ 라디칼 소거활성은 라디칼을 생성하는 $\mathrm{ABTS}$ 가 존재 시, hydrogen peroxide와 metmyoglobin의 빠른 항산화 반응에 의해 myoglobin radical을 감소시키는 기전으로 소 거활성을 나타낸다. ABTS 라디칼 소거활성에서(Fig. 2), 건조잎 추출물 농도 $200 \mathrm{\mu g} / \mathrm{mL}$ 에서 $94.1 \pm 3.6 \%, 40 \mu \mathrm{g} / \mathrm{mL}$ 에 서 $90.8 \pm 2.8 \%$ 로 생잎 추출물 $95.2 \pm 4.1 \%, 93.5 \pm 4.0 \%$ 와 비교 하여 유의적인 차이를 나타내지 않았지만, $8 \mathrm{\mu g} / \mathrm{mL}$ 에서 $33.6 \pm 2.5 \%, 38.2 \pm 1.6 \%$ 로 나타났다. 또한 $\mathrm{IC}_{50}$ 값은 건조잎 $10.7 \mu \mathrm{g} / \mathrm{mL}$, 생잎 $9.3 \mu \mathrm{g} / \mathrm{mL}$ 으로 나타났다. 환원력 평가는 시료의 환원력에 따라 노란색의 실험 용액이 청색 또는 녹색으로 전환되는 원리를 이용한 것이다. 항산화제와 같 은 환원제는 $\mathrm{Fe}^{3+} /$ ferricyanide complex를 환원시켜 ferrous 형태로 전환하고, 이로 인한 Perl's Prussian blue의 형성을 $700 \mathrm{~nm}$ 에서 측정하는 원리이다(22).

건조 방식에 따른 미선나무 잎 물 추출물의 환원력(Fig. 3)은 대조군으로 설정한 L-ascorbic acid(100\%)와 비교하여

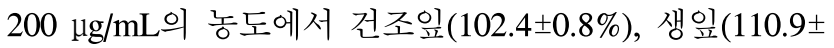
$1.4 \%)$ 의 환원력을 나타냈으며, 같은 농도의 대조군과 비교 하여 더 높은 효과를 나타냈다. 또한 생잎 처리군에서는 상당한 환원력을 나타냈다. 이러한 항산화 활성은 전자 공 여능과 밀접한 연관이 있으며 체내에서 생성되는 활성산소 종의 소거활성과 깊은 연관성을 가진다. 건조 방식에 따른 미선나무 잎 물 추출물은 높은 항산화 효과를 나타냈으며, 통계적으로 생잎의 활성이 건조 잎의 활성보다 높은 유의성 을 나타냈다. 


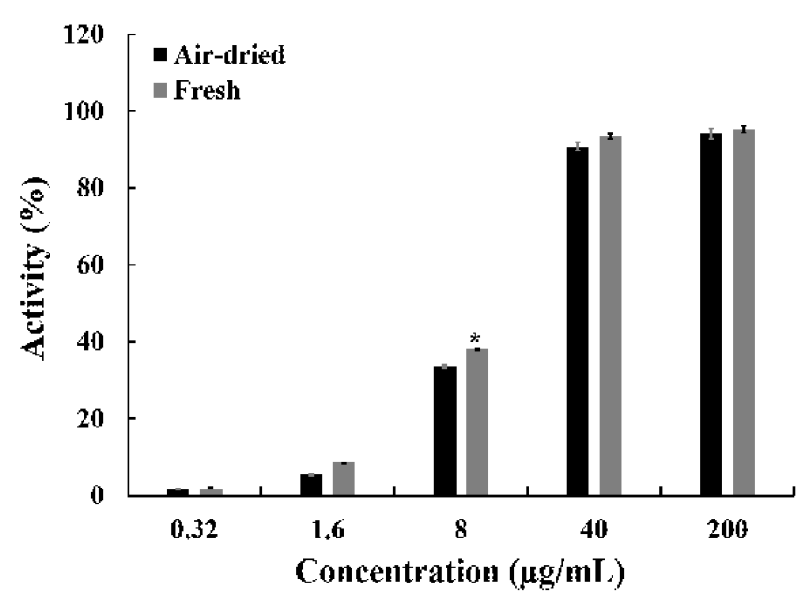

Fig. 2. ABTS radical scavenging activity of fresh and air-dried Abeliophyllum distichum Nakai leaves.

All data are from one experiment, representing three independent experiments $(\mathrm{p}<0.05$, air-dried-treated group vs fresh-treated group).

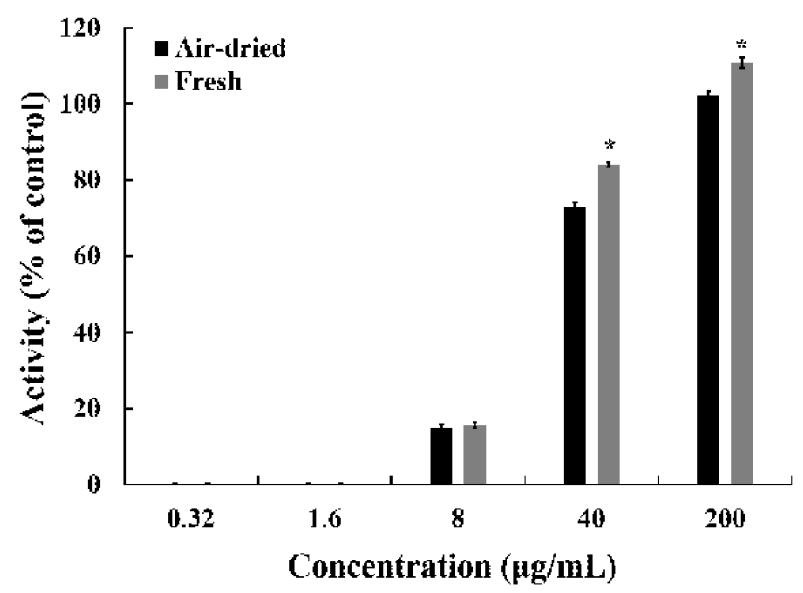

Fig. 3. Reducing power of leaves of fresh and air-dried Abeliophyllum distichum Nakai leaves.

All data are from one experiment, representing three independent experiments ( $\mathrm{p}<0.05$, air-dried-treated group vs fresh-treated group).

\section{페놀류 화합물 함량 분석}

건조 방식에 따른 미선나무 잎 물 추출물의 페놀류 화합 물을 분석한 결과(Fig. 4), 총 페놀류 화합물의 함량은 건조 잎 $(13.69 \mathrm{mg} / \mathrm{g} \mathrm{TAE})$, 생잎 $(13.61 \mathrm{mg} / \mathrm{g} \mathrm{TAE})$ 로 나타났다. 두 시료간의 페놀류 화합물의 함량은 차이가 없었다. 페놀 류 화합물의 항산화 활성은 그 구조적인 특징과 관련성이 높은데, 이들은 금속 킬레이트제, 환원제, 활성산소의 소거 제, 사슬전단 항산화제(chain breaking antioxidants)등으로 서의 역할에 기인하는 것으로 알려져 있다. 총 페놀성 화합 물은 다양한 구조와 분자량을 가진 2 차 대사산물로서 항산 화 활성과 항암, 항균, 항염증, 간 보호 효과 등 많은 생리적 작용을 하는 생리활성물질로 알려져 있다(23).

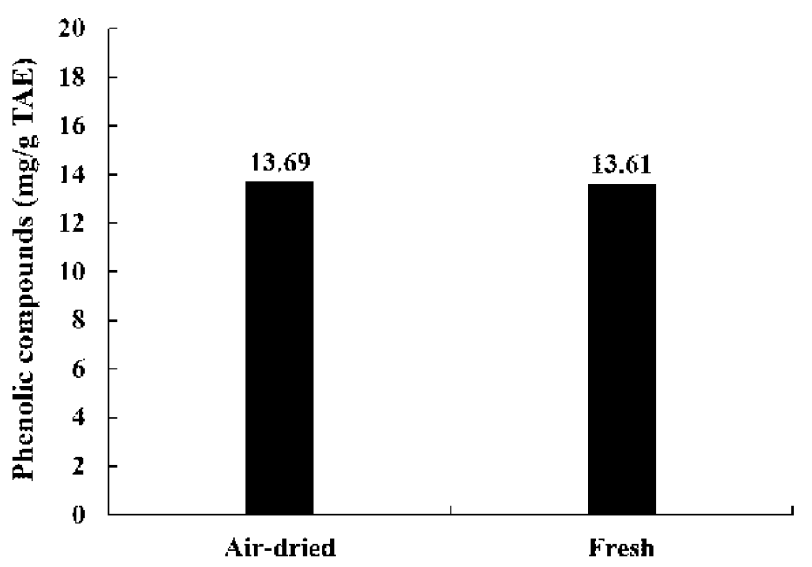

Fig. 4. Total phenolic compounds of fresh and air-dried Abeliophyllum distichum Nakai leaves.

$\mathrm{TAE}$, tannic acid equivalent.

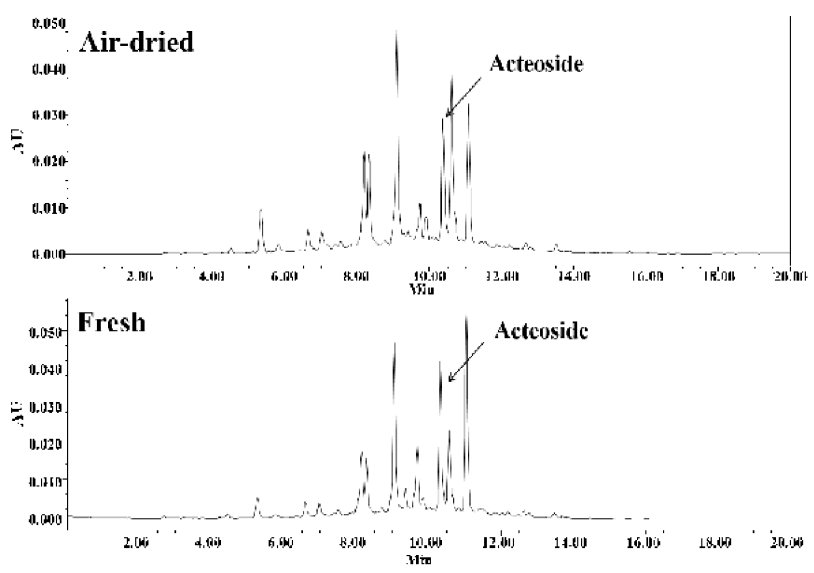

Fig. 5. Chromatogram of identification of acteoside of leaves of Abeliophyllum distichum Nakai according to drying methods by HPLC.

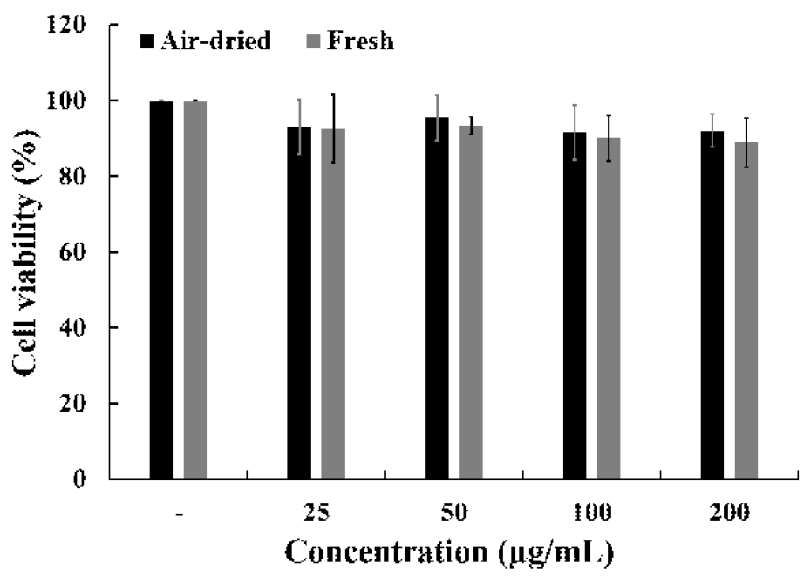

Fig. 6. Inhibitory effects of fresh and air-dried Abeliophyllum distichum Nakai leaves on cell viability.

RAW 264.7 macropahges were stimulated with treatments of air-dried and fresh leaves $(0,25,50,100 \mu \mathrm{g} / \mathrm{mL})$ for $24 \mathrm{~h}$. After incubation for $24 \mathrm{~h}$, cell viability was measured by using the alamarBlue ${ }^{\mathbb{B}}$ Cell Viability reagent. All data are from one experiment, representing three independent experiments. ( $\mathrm{p}<0.05$, non-treated group vs treated group). 


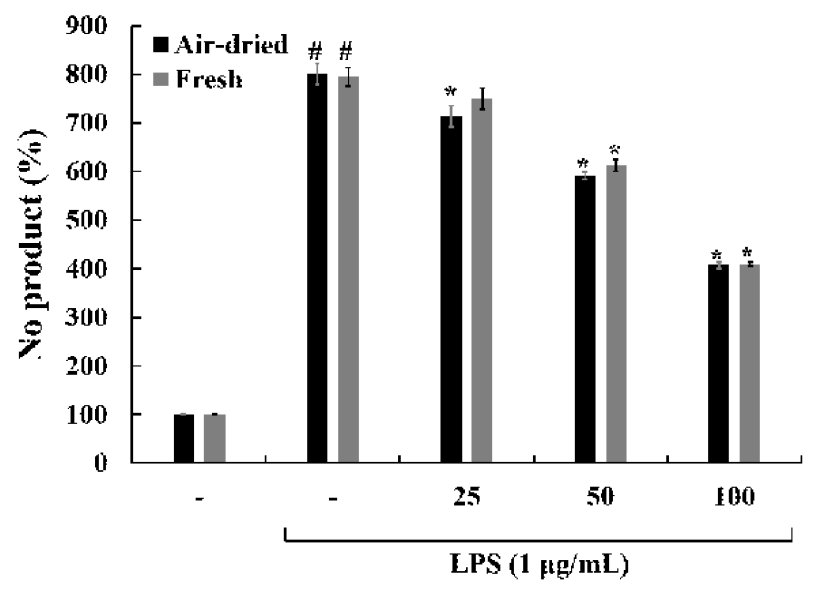

Fig. 7. Inhibitory effects of fresh and air-dried Abeliophyllum distichum Nakai leaves on the production of nitric oxide (NO).

RAW 264.7 macropahges were stimulated with treatments of Lipopolysaccharide (LPS), air-dried and fresh leaves $(0,25,50,100 \mu \mathrm{g} / \mathrm{mL})$ for $24 \mathrm{~h}$. After $24 \mathrm{~h}$ stimulation, NO secretion in the supernatants was measured by using th Griess reagent. NO secretion was calculated by using a standard curve according to sodium nitrite standard solution. Comparing with non-treated group (" $\mathrm{p}<0.05)$, LPS-treated group ( $\mathrm{p}<0.05)$. All data are from one experiment, representing three independent experiments.

(A)

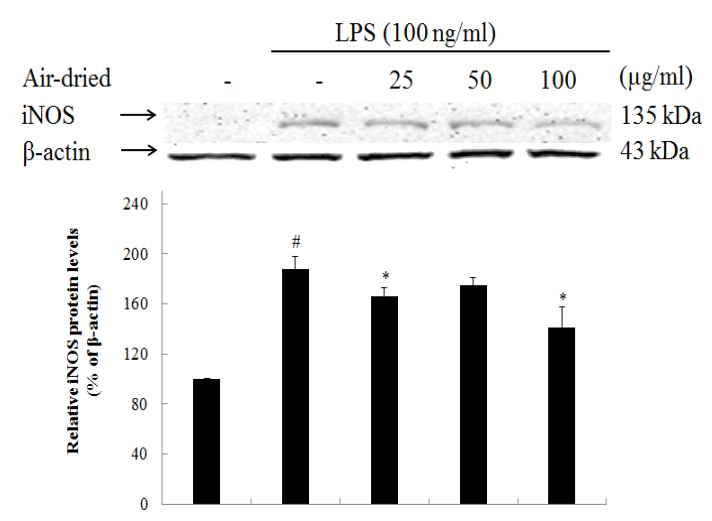

(C)

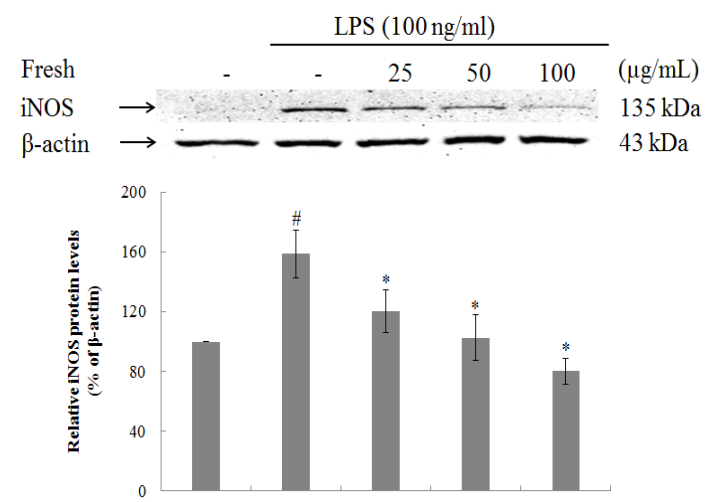

\section{Acteoside 함량 분석}

건조 방식에 따른 미선나무 잎 물 추출물의 acteoside 분석한 결과(Fig. 5), 건조잎 $(9.5 \mathrm{mg} / \mathrm{g})$, 생잎 $(13.2 \mathrm{mg} / \mathrm{g})$ 으로 생잎의 acteoside 함량이 높았다. 물푸레나무과에 포함된 acteoside는 다양한 생리활성을 나타낸다고 알려져 있으며 (24), 미선나무의 다양한 활성관 연관성이 깊다고 사료된다.

\section{세포 생존율}

건조 방식에 따른 미선나무 잎 물 추출물의 세포 생존률 은 MTS 분석을 통해 실시하였으며, $25,50,100,200 \mu \mathrm{g} / \mathrm{mL}$ 의 농도로 처리한 결과(Fig. 6), 건조잎 $92.9 \pm 7.1 \%$, $95.4 \pm 6.1 \%, 91.5 \pm 7.1 \%, 92.0 \pm 4.3 \%$ 으로 나타났으며, 생잎 $92.6 \pm 9.0 \%, 93.4 \pm 2.3 \%, 90.0 \pm 6.1 \%, 88.8 \pm 6.4 \%$ 으로 RAW 264.7 세포의 생존율에 영향을 미치지 않았다. 따라서 건조 방식에 따른 미선나무 잎 물 추출물의 세포 독성은 확인되 지 않았다.

(B)

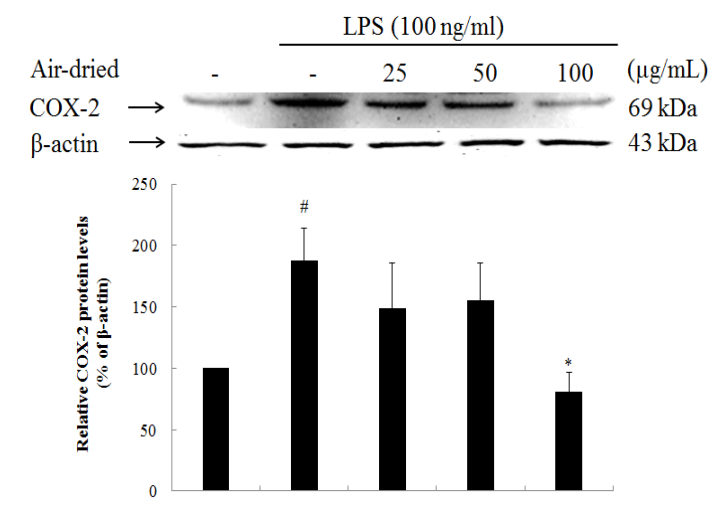

(D)

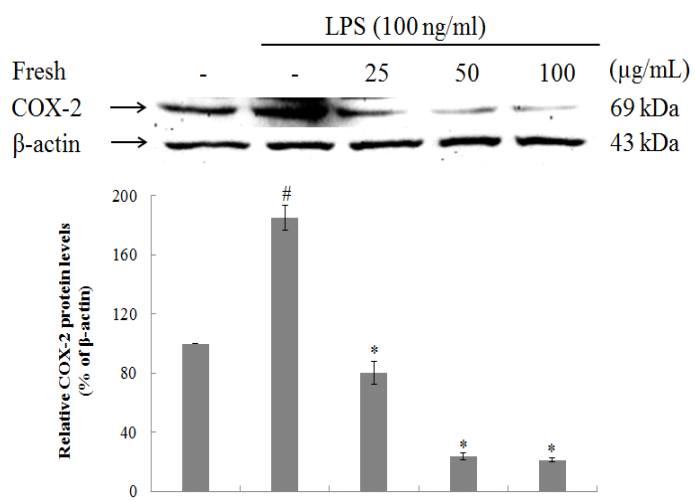

Fig. 8. Inhibitory effects of fresh and air-dried Abeliophyllum distichum Nakai leaves on the expression of iNOS and COX-2 protein. RAW 264.7 macropahges were stimulated with treatments of Lipopolysaccharide (LPS), air-dried and fresh leaves (0, 25, 50, $100 \mu \mathrm{g} / \mathrm{mL})$ for $24 \mathrm{~h}$. After $24 \mathrm{~h}$ stimulation, total cell lysates were subjected to Western blotting analysis. The protein expression of iNOS and COX-2 was detected by using an enhanced chemiluminescence reagent. Those levels were quantified by analysis with the software Un-SCAN-IT gel Version 5.1 (Silk Scientific, Inc.) and normalized to cortesponding $\beta$-actin levels. Comparing with non-treated group $(" \mathrm{p}<0.05)$, LPS-treated group $\left.{ }^{*} \mathrm{p}<0.05\right)$. All data are from one experiment, representing three independent experiments. 
(A)

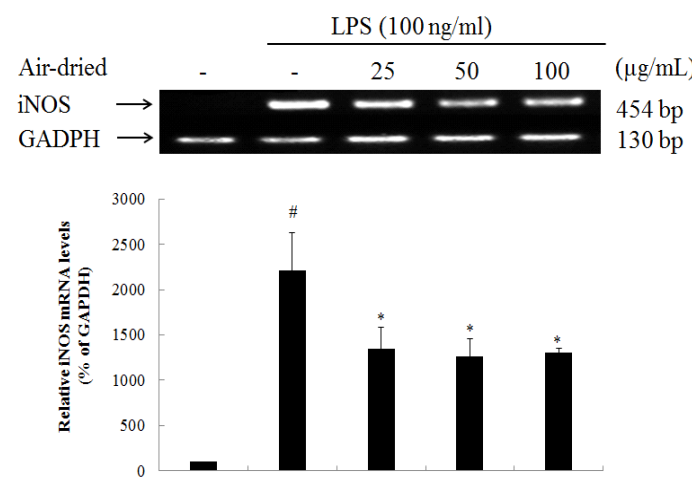

(C)

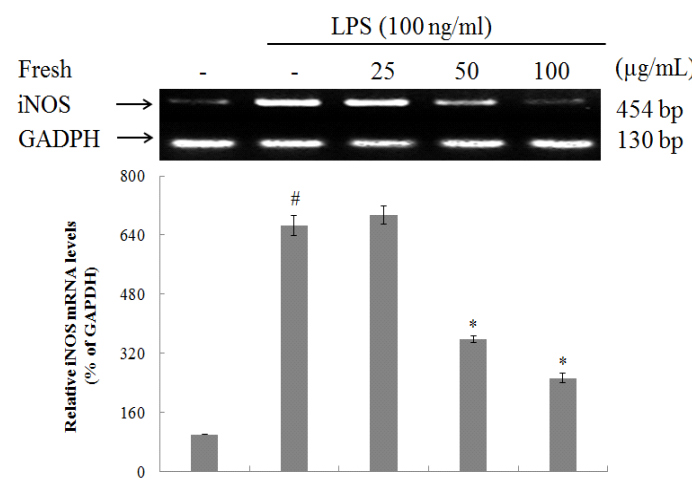

(B)

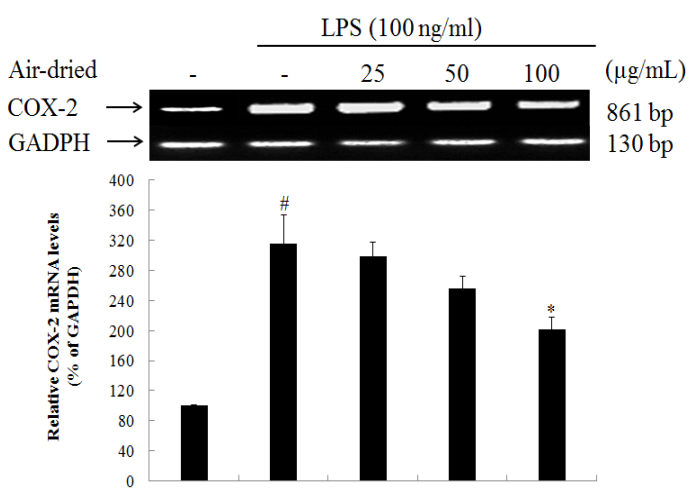

(D)

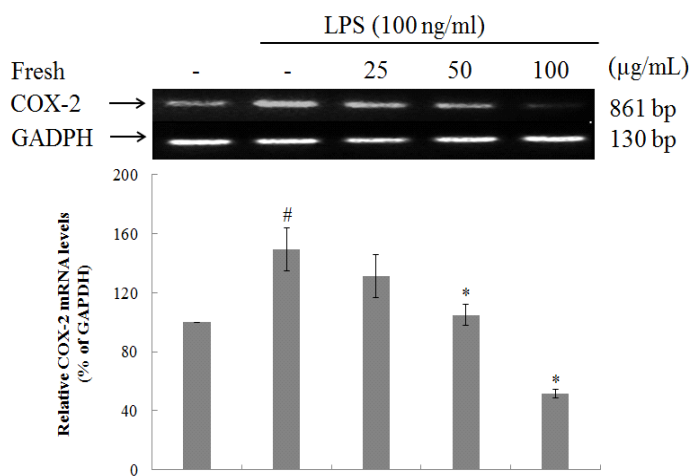

Fig. 9. Inhibitory effects of Abeliophyllum distichum Nakai leaves on the mRNA levels of iNOS and COX-2.

RAW 264.7 macropahges were stimulated with treatments of Lipopolysaccharide (LPS), air-dried and fresh leaves (0, 25, 50, $100 \mu \mathrm{g} / \mathrm{mL})$ for $6 \mathrm{~h}$. After $6 \mathrm{~h}$ stimulation, total cell lysates were subjected to RT-PCR analysis. The mRNA levels of iNOS and COX-2 was detected by DNA electrophoresis. Those levels were quantified by analysis with the software Un-SCAN-IT gel Version 5.1 (Silk Scientific, Inc.) and normalized to corresponding GAPDH levels. Comparing with non-treated group ("p<0.05), LPS-treated group $(\mathrm{p}<0.05)$. All data are from one experiment, representing three independent experiments.

\section{항염증 활성}

Pro-inflammatory cytokines, prostaglandins과 NO 생성은 활성화된 대식세포에서 염증 반응에서 중요한 역할을 한다 $(25,26) . \mathrm{NO}$ 는 Inducible nitric oxide synthase(iNOS)에 의해 L-arginine으로부터 생성되며, 정상적인 상태에서는 신경 전달, 혈관 확장, 면역 반응 등의 생리적인 기능을 조절하는 중요한 역할을 하지만(27,28), 염증 반응에서 과발현된 $\mathrm{NO}$ 는 혈관 투과성을 증가시켜 부종을 일으키고 염증을 심화시 켜 다양한 세포 및 조직손상을 일으켜 만성 염증 질환 및 자가면역질환 등을 초래하는 것으로 알려져 있다(29). 건조 방식에 따른 미선나무 잎 물 추출물의 nitric oxide(NO) 수준 을 확인한 결과(Fig. 7), LPS 처리에 의해 증가된 NO는 처리된 시료에 의해 농도 의존적으로 감소하였다. 추출물 농도 $100 \mu \mathrm{g} / \mathrm{mL}$ 에서 두 시료간의 차이는 없었지만, LPS 처리군에 비해 약 $50 \% \mathrm{NO}$ 생성량이 감소하였다.

$\mathrm{iNOS}$ 의 발현은 세포내 $\mathrm{Ca}^{2+}$ 농도와 관계없이 세균성 독 소 또는 염증 및 면역반응, 허혈, 조직손상, 산화성 스트레스 등에 따라 유리되는 여러 종류의 cytokine에 의해서 유전자 전사단계에서 유도되며, 이에 따라 $\mathrm{NO}$ 가 대량 생성 유리될 경우에는 질병의 병태생리에 중요한 인자로 관여할 수 있다
(30). COX-2는 염증 반응뿐만 아니라 혈액응고, 신장기능, 혈관조절 및 면역 반응 등에 관여하고, 염증성 cytokine이 분비되면 COX-2가 활성화 된다(31). 또한 COX-2는 염증조 직, 악성 종양조직에서 정상 세포에 비해 많은 양의 프로스 타글란딘의 생성을 유도하여 혈관 생성을 촉진하고 세포의 증식을 도울 뿐 아니라 면역능력을 억제함으로써 암세포 성장에 좋은 환경을 제공하여 $\mathrm{COX}-2$ 의 발현은 또 다른 질병의 병원성과 직접적인 연관성을 나타낸다(32).

건조 방식에 따른 미선나무 잎 물 추출물의 iNOS 및 COX-2 단백질 발현을 확인한 결과(Fig. 8), iNOS 단백질 발현은 $25,50,100 \mu \mathrm{g} / \mathrm{mL}$ 에서 모두 감소하였다. 또한 생잎 추출물 농도 $100 \mu \mathrm{g} / \mathrm{mL}$ 에서는 LPS무처리군의 iNOS 발현 량과 비슷한 수준의 감소효과를 보였다. COX-2 단백질 발 현은 건조잎의 활성이 낮았으며, 생잎 추출물 농도 25,50 , $100 \mu \mathrm{g} / \mathrm{mL}$ 에서 모두 높은 감소효과를 보였다. 건조 방식에 따른 미선나무 잎 물 추출물의 iNOS 및 COX-2 mRNA 수준을 확인한 결과(Fig. 9), iNOS mRNA 수준은 25, 50, $100 \mu \mathrm{g} / \mathrm{mL}$ 에서 모두 감소하였다. 하지만 생잎 추출물 농도 $25 \mu \mathrm{g} / \mathrm{mL}$ 에서는 LPS 처리군의 iNOS 발현량과 비슷한 수준 으로 iNOS mRNA의 감소효과를 나타내지 않았다. COX-2 
mRNA 수준이 발현은 건조잎의 활성이 낮았으며, 생잎 추 출물 농도 $50,100 \mu \mathrm{g} / \mathrm{mL}$ 에서 높은 감소효과를 보였다. 건조 잎 추출물 농도 $25,50 \mu \mathrm{g} / \mathrm{mL}$ 는 COX-2 mRNA의 발현저해 효과가 없었다. 결론적으로 염증 바생과 관련이 깊은 $\mathrm{iNOS}$ 및 COX-2 인자의 단백질 발현 및 $\mathrm{mRNA}$ 수준의 경감효과 가 상당하였으며 생잎의 활성이 건조잎의 활성보다 높았 다.

본 연구에서 건조 방식에 따른 미선나무 잎 물 추출물은 LPS로 활성화된 대식세포의 $\mathrm{NO}$ 생성을 억제하는 것을 확 인하였다. 또한 iNOS 및 COX-2 단백질 발현 및 mRNA 수준의 저해효과를 확인하였으며, 이러한 효과는 페놀화합 물뿐만 아니라 미선나무가 포함하고 있는 acteoside의 함량 에 직간접적인 상관관계가 있다고 사료된다. 이를 통해 건 조 방식에 따라 미선나무 잎의 항염증 및 항산화 활성 변화 를 확인하였다.

\section{요 약}

건조 방식에 따른 미선나무 잎의 항산화 활성 및 항염증 효과를 확인한 결과, 높은 항산화 활성를 나타냈으며, 건조 잎에 비해 생잎의 항산화 활성이 뛰어났다. 페놀류 화합물 의 함량은 유의적인 차이가 없었으나, 미선나무의 활성물 질로 알려진 acteoside의 함량을 분석한 결과, 생잎의 acteoside의 함량이 높았다. 또한 항염증 효과를 확인하기 위해 nitric oxide의 함량 및 세포 수준에서의 염증 관련 인자인 iNOS와 COX-2의 단백질 발현 및 mRNA 수준을 확인한 결과, 생잎의 억제활성이 건조잎보다 높았다. 이를 통해 건조 잎에 비해 생잎의 이용가치가 높았으며, 이러한 항산화 및 항염증 활성은 acteoside의 함량의 차이와 밀접한 관련이 있는 것으로 사료된다.

\section{References}

1. Maxwell SR (1995) Prospects for the use of antioxidant therapies. Drugs, 49, 345-361

2. Asensi M, Ortega A, Mena S, Feddi F, Estrela JM (2011) Natural polyphenols in cancer therapy. Crit Rev Clin Lab Sci, 48, 197-216

3. Kehrer JP (1993) Free radicals as mediators of tissue injury and disease. Crit Rev Toxicol, 23, 21-48

4. Lawrence T, Willoughby DA, Gilroy DW (2002) Anti-inflammatory lipid mediators and insights into the resolution of inflammation. Nat Rev Immunol, 2, 787-795

5. Choi DS (2009) Study on the antiinflammatory effect and mechanism of isoegomaketone in vitro and in vivo.
MS Thesis, Chonbuk National University, Korea, p 4-5

6. Chae CH (2004) Functional role of inducible nitric oxide synthase and cyclooxygenase- 2 in acute inflammation. Ministry of Health and Welfare, Gwacheon, Korea, p 10-11

7. Bak JP, Son JH, Kim YM, Jung JH, Leem KH, Lee EY, Kim EH (2011) Suppression effect of the inflammatory response in macrophages by paeoniae radix rubra extracts. Korean J Med Crop Sci, 19, 373-379

8. Jung HK, Kang BM, Jang JH, Ahn BK, Yeo JH, Jung WS, Cho JH, Kuk YI, Hyun KH, Cho HW (2014) Inhibitory effect of Alopecurus aequalis Sobol ethanol extracts on LPS-induced inflammatory response in RAW 264.7 cells. Korean J Med Crop Sci, 22, 98-104

9. Park JH (2011) Antioxidant activities and inhibitory effect on oxidative DNA damage of extracts from abeliophylli distichi folium. Korean J Herbol, 26, 95-99

10. Oh H, Kang DG, Kwon TO, Jang KK, Chai KY, Yun YG, Chung HT, Lee HS (2003) Four glycosides from the leaves of Abeliophyllum distichum with inhibitory effects on angiotensin converting enzyme. Phytother Res, $17,811-813$

11. Park GH, Park JH, Eo HJ, Song HM, Lee MH, Lee JR, Jeong JB (2014) Anti-inflammatory effect of the extracts from Abeliophyllum distichum Nakai in LPS-stimulated RAW264.7 cells. Korean J Plant Res, 27, 209-214

12. Xiong Q, Hase K, Tezuka Y, Tani T, Namba T, Kadota S (1998) Hepatoprotective activity of phenylethanoids from Cistanche deserticola. Planta Med, 64, 120-125

13. Schlesier K, Harwat M, Bohm V, Bitsch R (2002) Assessment of antioxidant activity by using different in vitro methods. Free Radic Res, 36, 177-187

14. He ZD, Lau KM, Xu HX, Li PC, Pui-Hay BP (2000) Antioxidant activity of phenylethanoid glycosides from Brandisia hancei. J Ethnopharmacol, 71, 483-486

15. Li J, Wang PF, Zheng R, Liu ZM, Jia Z (1993) Protection of phenylpropanoid glycosides from pedicularis against oxidative hemolysis in vitro. Planta Med, 59, 315-317

16. Xiong Q, Kadota S, Tani T, Namba T (1996) Antioxidative effects of phenylethanoids from Cistanche deserticola. Biol Pharm Bull, 19, 1580-1585

17. Bondet V, Brand-Williams W, Berset C (1997) Kinetics and mechanisms of antioxidant activity using the DPPH free radical method. LWT-Food Sci Technol, 30, 609-615

18. Van den Berg R, Haenen GR, Van den Berg H, Bast A (1999) Applicability of an improved trolox equivalent antioxidant capacity (TEAC) assay for evaluation of 
antioxidant capacity measurements of mixtures. Food Chem, 66, 511-517

19. Oyaizu M (1986) Studies on products of browning reaction: antioxidative activities of products of browning reaction prepared from glucosamine. Jpn J Nutr, 44, 307-315

20. AOAC (1995) Official Methods of Analysis. $14^{\text {th }} \mathrm{ed}$, Association of Official Analytical Chemists, Washington DC, USA, p 8-35

21. Que F, Mao L, Pan X (2006) Antioxidant activities of five Chinese rice wines and the involvement of phenolic compounds. Food Res Int, 39, 581-587

22. Ferreira IC, Baptista P, Vilas-Boas M, Barros L (2007) Free-radical scavenging capacity and reducing power of wild edible mushrooms from northeast Portugal: Individual cap and stipe activity. Food Chem, 100, 1511-1516

23. Ferreres F, Gomes D, Valentano P, Goncalves R, Pio R, Chagas EA, Seabra RM, Andrade PB (2009) Improved loquat (Eriobotrya japonica Lindl.) cultivars: Variation of phenolics and antioxidative potential. Food Chem, 114, 1109-1127

24. Bremer B, Bremer K, Heidari N, Erixon P, Olmstead RG, Anderberg AA, Kallersjo M, Barkhordarian E (2002) Phylogenetics of asterids based on 3 coding and 3 non-coding chloroplast DNA markers and the utility of non-coding DNA at higher taxonomic levels. Mol Phylogenet Evol, 24, 274-301

25. Szabo C (1998) Role of nitric oxide in endotoxic shock: An overview of recent advances. Ann N Y Acad Sci, $851,422-425$

26. Martel-Pelletier J, Pelletier JP, Fahmi H (2003) Cyclooxygenase-2 and prostaglandins in articular tissues. Semin Arthritis Rheum, 33, 155-167
27. Weisz A, Cicatiello L, Esumi H (1996) Regulation of the mouse inducible-type nitric oxide synthase gene promoter by interferongamma, bacterial lipopolysaccharide and NG-monomethyl-L-arginine. Biochem J, 316, 209-215

28. An SM, Kim HG, Choi EJ, Hwang HH, Lee ES, Baek JH, Boo YC, Koh JS (2014) Screening for anti-inflammatory activities in extracts from Korean herb medicines. J Soc Cosmet Sci Korea, 40, 95-108

29. Kang CH, Choi YH, Choi IW, Lee JD, Kim GY (2011) Inhibition of lipopolysaccharide-induced iNOS, COX-2, and TNF-a expression by aqueous extract of Orixa japonica in Raw 264.7 cells via suppression of NF- $k B$ activity. Trop J Pharm Res, 10, 161-168

30. Hur GM, Ryu YS, Yun HY, Jeon BH, Kim YM, Seok JH, Lee JH (1999) Hepatic ischemia/reperfusion in rats induces iNOS gene transcription by activation of NF-kappaB. Biochem Biophys Res Commun, 261, 917-922

31. Sato T, Nakajima H, Fujio K, Mori Y (1997) Enhancement of prostaglandin E2 production by epidermal growth factor requires the coordinate activation of cytosolic phospholipase A2 and cyclooxygenase 2 in human squamous carcinoma A431 cells. Prostaglandins, 53, 355-369

32. Huang M, Stolina M, Sharma S, Mao JT, Zhu L, Miller PW, Wollman J, Herschman H, Dubinett SM (1998) Non-small cell lung cancer cyclooxygenase-2-dependent regulation of cytokine balance in lymphocytes and macrophages: up-regulation of interleukin 10 and down-regulation of interleukin 12 production. Cancer Res, 58, 1208-1216 